\title{
Rhodobacter changlensis sp. nov., a psychrotolerant, phototrophic alphaproteobacterium from the Himalayas of India
}

\author{
Correspondence \\ Ch. V. Ramana \\ r449@sify.com \\ or \\ sasi449@yahoo.ie
}

\author{
P. Anil Kumar, ${ }^{1}$ T. N. R. Srinivas, ${ }^{1}$ Ch. Sasikala ${ }^{1}$ and Ch. V. Ramana ${ }^{2}$ \\ ${ }^{1}$ Bacterial Discovery Laboratory, Centre for Environment, Institute of Science and Technology, \\ J. N. T. University, Kukatpally, Hyderabad 500 085, India \\ ${ }^{2}$ Department of Plant Sciences, School of Life Sciences, University of Hyderabad, PO Central \\ University, Hyderabad 500 046, India
}

\begin{abstract}
A Gram-negative, non-motile, oval to rod-shaped, psychrotolerant, phototrophic, purple nonsulfur bacterium (designated strain $\mathrm{JA} 139^{\top}$ ) was isolated from a snow sample from Changla Pass in the Indian Himalayas. Strain $\mathrm{JA} 139^{\top}$ had vesicular-type intracytoplasmic membrane structures and contained bacteriochlorophyll $a$ and most probably spheroidene-like carotenoids. Biotin, niacin and thiamine were required for growth of strain $\mathrm{JA} 139^{\top}$. Phylogenetic analysis on the basis of $16 S$ rRNA gene sequences showed that the strain clustered with species of the genus Rhodobacter but was distinctly separate from all recognized members of the family Rhodobacteraceae. Based on the genotypic and phenotypic differences observed between strain $\mathrm{JA} 139^{\top}$ and recognized Rhodobacter species, strain $\mathrm{JA} 139^{\top}$ is considered to represent a novel species of the genus, for which the name Rhodobacter changlensis sp. nov. is proposed. The type strain is JA $139^{\top}\left(=\mathrm{DSM} 18774^{\top}=\right.$ CCUG $\left.53722^{\top}=\mathrm{JCM} 14338^{\top}\right)$.
\end{abstract}

Anoxygenic phototrophic bacteria are found widely distributed in various habitats including those from the extreme cold. Among such species reported from cold environments are Rhodoferax antarcticus (Madigan et al., 2000) isolated from an Antarctic microbial mat and Rhodoferax ferrireducens (Finneran et al., 2003) isolated from subsurface marine sediments of Oyster Bay, USA, both of which represent phototrophic members of the class Betaproteobacteria. Here we describe a novel psychrotolerant phototroph belonging to the genus Rhodobacter (class Alphaproteobacteria).

Strain $\mathrm{JA} 39^{\mathrm{T}}$ was isolated from photoheterotrophic enrichments of a snow sample from Changla Pass in the Himalayas of India. Purification and polyphasic taxonomic studies were carried out as described by Srinivas et al. (2006). Sequences were aligned by using the CLUSTAL X program (Thompson et al., 1997) and the alignment was corrected manually. The CLUSTAL $\mathrm{x}$ alignment file was used as input file to the SEQBOOT program in the PHYLIP package and the output file of SEQBOOT was used as the input file for maximum-likelihood analysis based on 100 datasets and

The GenBank/EMBL/DDBJ accession number for the 16S rRNA gene sequence of strain $\mathrm{JA} 139^{\top}$ is $\mathrm{AM} 399030$.

A photograph showing the yellowish-brown-coloured snow sample collected from Changla Pass, Indian Himalayas, from where strain $\mathrm{JA} 139^{\top}$ was isolated, a phase-contrast micrograph of cells of strain $\mathrm{JA} 139^{\top}$ and the whole-cell absorption spectrum of strain $\mathrm{JA} 139^{\top}$ are available as supplementary material with the online version of this paper. five times jumbling. One single tree was produced by using 100 trees generated during maximum-likelihood analysis with the CONSENSE program. A final dendrogram with evolutionary distances was contructed by taking the alignment.phy file as the infile and the consensus tree as the intree in the maximum-likelihood program within the PHYLIP package (Felsenstein, 1989).

A yellowish-brown-coloured snow sample (see Supplementary Fig. S1 in IJSEM Online) was collected on 22 May 2006 from Changla Pass $(\sim 5640 \mathrm{~m}$ above sea level) in the Indian Himalayas $\left(34^{\circ} 10^{\prime} \mathrm{N} 78^{\circ} 16^{\prime} \mathrm{E}\right)$. Individual cells of strain $\mathrm{JA} 139^{\mathrm{T}}$ were oval to rod shaped, $0.8-1.0 \mu \mathrm{m}$ wide and 2-4 $\mu \mathrm{m}$ long, and usually formed chains; they were non-motile and multiplied by binary fission (Supplementary Fig. S2). Electron micrographs of ultrathin sections of the cells revealed vesicular-type intracytoplasmic membrane structures.

Strain JA139 ${ }^{\mathrm{T}}$ was able to grow photo-organoheterotrophically [anaerobically in the light $(2400 \mathrm{~lx})$ ] and chemoorganoheterotrophically [aerobically in the dark, with pyruvate $(0.3 \%, \mathrm{w} / \mathrm{v})]$. We were unable to demonstrate photolithoautotrophy [anaerobically in the light $(2400 \mathrm{~lx})$, with $\mathrm{Na}_{2} \mathrm{~S} \quad(0.5 \mathrm{mM}), \quad \mathrm{Na}_{2} \mathrm{~S}_{2} \mathrm{O}_{3} \cdot 5 \mathrm{H}_{2} \mathrm{O} \quad(0.5 \mathrm{mM})$ or $\mathrm{NaHCO}_{3}(0.1 \%$, w/v)], chemolithoautotrophy [aerobically in the dark, with thiosulfate $(0.5 \mathrm{mM})$ or $\mathrm{NaHCO}_{3}(0.1 \%$, $\mathrm{w} / \mathrm{v})$ ] or fermentative growth [anaerobically in the dark, with pyruvate $(0.3 \% \mathrm{w} / \mathrm{v})$ ] for strain JA139 ${ }^{\mathrm{T}}$. Substrates that could be utilized as carbon/electron donors under 
Table 1. Differential phenotypic characteristics among members of the genus Rhodobacter

Symbols: + , substrate utilized or present; -, substrate not utilized or absent; \pm , variable in different strains; $(+)$, weak growth; NR, not reported. Organic substrate utilization was tested during photoheterotrophic growth. Cells of all taxa divide by binary fission. Pyruvate, succinate and Dglucose were utilized by all taxa. Benzoate and arginine were not utilized by any of the taxa.

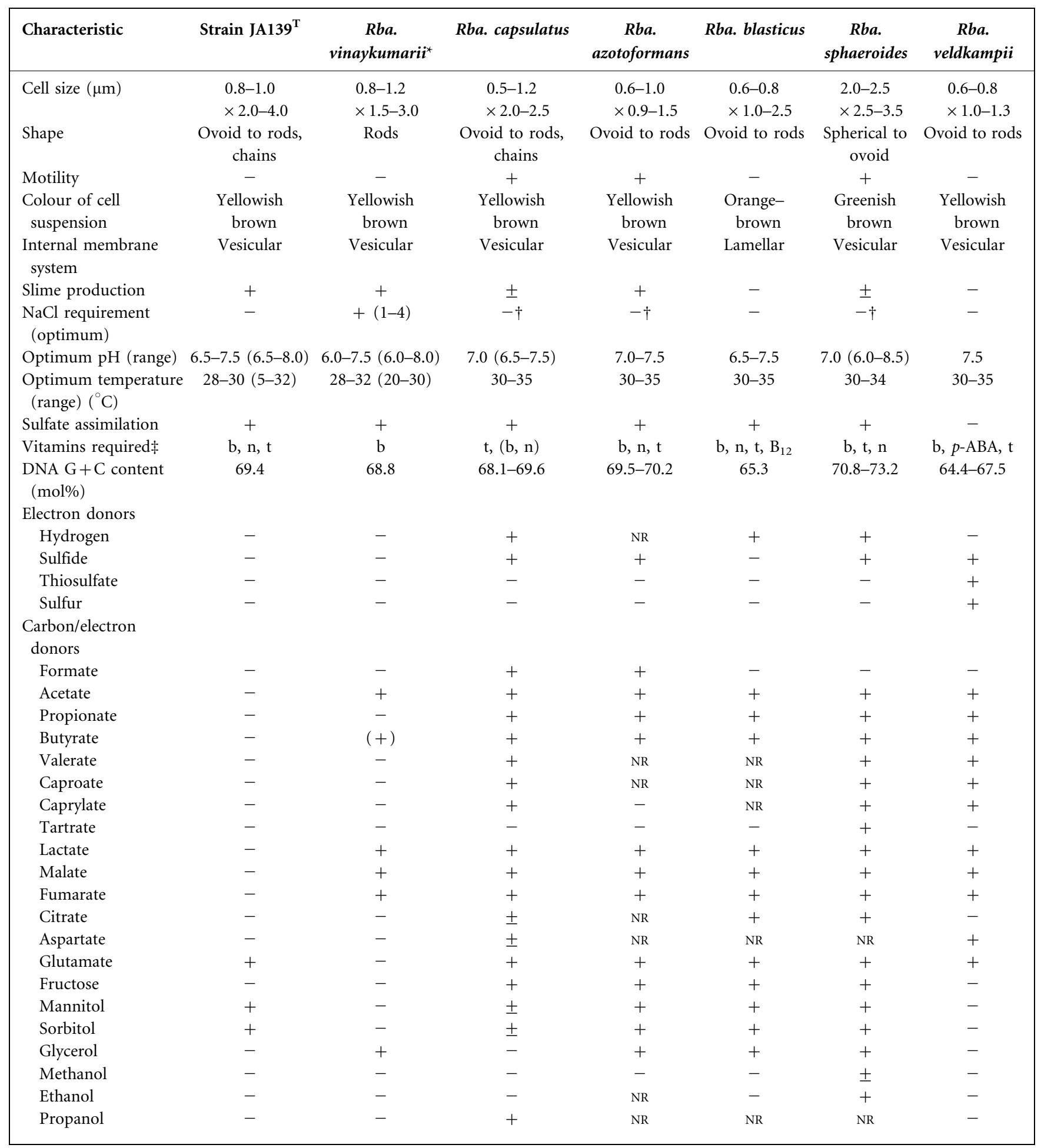

*Source data updated from Srinivas et al. (2007).

†Optimal growth in the absence of $\mathrm{NaCl}$ but able to grow at $3 \% \mathrm{NaCl}$.

$\neq$ b, Biotin; $B_{12}$, vitamin $B_{12} ; n$, niacin; $p$ - $A B A$, $p$-aminobenzoic acid; $t$, thiamine; $(b, n)$, a few strains require biotin and/or niacin. 
photo-organoheterotrophic conditions at $28 \pm 2{ }^{\circ} \mathrm{C}$ included pyruvate, 2-oxoglutarate, succinate, glucose, mannitol, sorbitol, glutamate, casein hydrolysate, yeast extract and peptone (see Table 1). Formate, acetate, propionate, butyrate, valerate, crotonate, caproate, caprylate, lactate, gluconate, glycolate, benzoate, tartrate, malate, fumarate, citrate, fructose, sucrose, lactose, starch, glycerol, aspartate, methionine, cysteine, ascorbate, methanol, ethanol, propanol and butanol could not be utilized. Strain $\mathrm{JA} 139^{\mathrm{T}}$ was able to use ammonium chloride, glutamine and $\mathrm{N}_{2}$ as nitrogen sources, but not urea, nitrate or nitrite. Sulfate and thioglycolate were utilized as sulfur sources, but not sulfite, sulfur, sulfide, thiosulfate or cysteine. Although $\mathrm{NaCl}$ was not obligatory for growth of strain JA139 ${ }^{\mathrm{T}}$, optimum growth occurred at $0.1 \%(\mathrm{w} / \mathrm{v})$. The $\mathrm{pH}$ range for growth of strain $\mathrm{JA} 139^{\mathrm{T}}$ was $6.5-9$ with an optimum at $\mathrm{pH}$ 6.5-7.5. The optimum temperature for growth was $28 \pm 2{ }^{\circ} \mathrm{C}$, but growth was observed from 5 to $32{ }^{\circ} \mathrm{C}$. The biomass yield of strain JA139 $9^{\mathrm{T}}$ grown at $5{ }^{\circ} \mathrm{C}$ was about $50 \%$ of that grown at the optimum temperature. Strain JA139 ${ }^{\mathrm{T}}$ grew well in the presence of fluorescent light (optimum light intensity $2000 \mathrm{~lx}$; range 1000-3000 lx). Furthermore, strain JA139 ${ }^{\mathrm{T}}$ required biotin, niacin and thiamine as growth factors. The photosynthetically grown cell suspension was yellowish brown. The whole-cell absorption spectrum of strain $\mathrm{JA} 139^{\mathrm{T}}$ gave absorption maxima at 380,407, 450, 470,512, 590, 806 and $851 \mathrm{~nm}$, confirming the presence of bacteriochlorophyll $a$, and most probably carotenoids of the spheroidene series (Supplementary Fig. S3). The DNA base composition of strain $\mathrm{JA}_{139^{\mathrm{T}}}$ was $69.4 \mathrm{~mol} \% \mathrm{G}+\mathrm{C}$ (by HPLC). The phylogenetic relationship of strain $\mathrm{JA} 139^{\mathrm{T}}$ to other purple non-sulfur bacteria was examined by $16 \mathrm{~S}$ rRNA gene sequencing. The data obtained revealed that the new isolate branched separately but clustered with the type strains of species of the genus Rhodobacter and was distinct from other genera of purple non-sulfur bacteria. Strain JA139 ${ }^{\mathrm{T}}$ showed highest 16S rRNA gene sequence similarities with the type strains of Rhodobacter sphaeroides (94.6\%), Rhodobacter azotoformans (94.4\%), Rhodobacter veldkampii (93.6\%), Rhodobacter blasticus (92.7\%), Rhodobacter capsulatus (92.5\%) and Rhodobacter vinaykumarii (93.1\%; Srinivas et al., 2007) (Fig. 1). In addition to showing $16 \mathrm{~S}$ rRNA gene sequence divergence, strain $\mathrm{JA} 139^{\mathrm{T}}$ showed clear phenotypic differences from recognized Rhodobacter species (Table 1) that justify the description of this strain as representing a novel species, for which the name Rhodobacter changlensis sp. nov. is proposed.

\section{Description of Rhodobacter changlensis sp. nov.}

Rhodobacter changlensis (chang.len'sis. N.L. masc. adj. changlensis pertaining to Changla Pass, the location from where the type strain was isolated).

Cells are oval to rod-shaped, $0.8-1.0 \mu \mathrm{m}$ wide and $2-4 \mu \mathrm{m}$ long, are non-motile and divide by binary fission, and occasionally form chains. Growth occurs under anaerobic conditions in the light (photo-organoheterotrophy) or under aerobic conditions in the dark (chemo-organoheterotrophy). Internal photosynthetic membranes are of the vesicular type. Phototrophic cultures are yellowish brown. The in vivo absorption spectrum of intact cells in sucrose exhibits maxima at 380, 407, 450, 470, 512, 590, 806 and $851 \mathrm{~nm}$, confirming the presence of bacteriochlorophyll $a$ and most probably carotenoids of the spheroidene series. The organism is psychrotolerant (range $5-32{ }^{\circ} \mathrm{C}$; optimum at $28 \pm 2{ }^{\circ} \mathrm{C}$ ), has a pH optimum at $6.5-7.5$ and does not require $\mathrm{NaCl}$ for growth. Photo-organoheterotrophy with a few organic compounds is the preferred mode of growth. Grows well on pyruvate, 2-oxoglutarate, mannitol and sorbitol as carbon sources. Growth is also observed on succinate, glucose, glutamate, casein hydrolysate, yeast extract and peptone. Chemoautotrophic growth is not possible in the presence of thiosulfate/hydrogen as electron donor and $\mathrm{NaHCO}_{3}$ as carbon source. Fermentative growth is not possible in the presence of pyruvate as

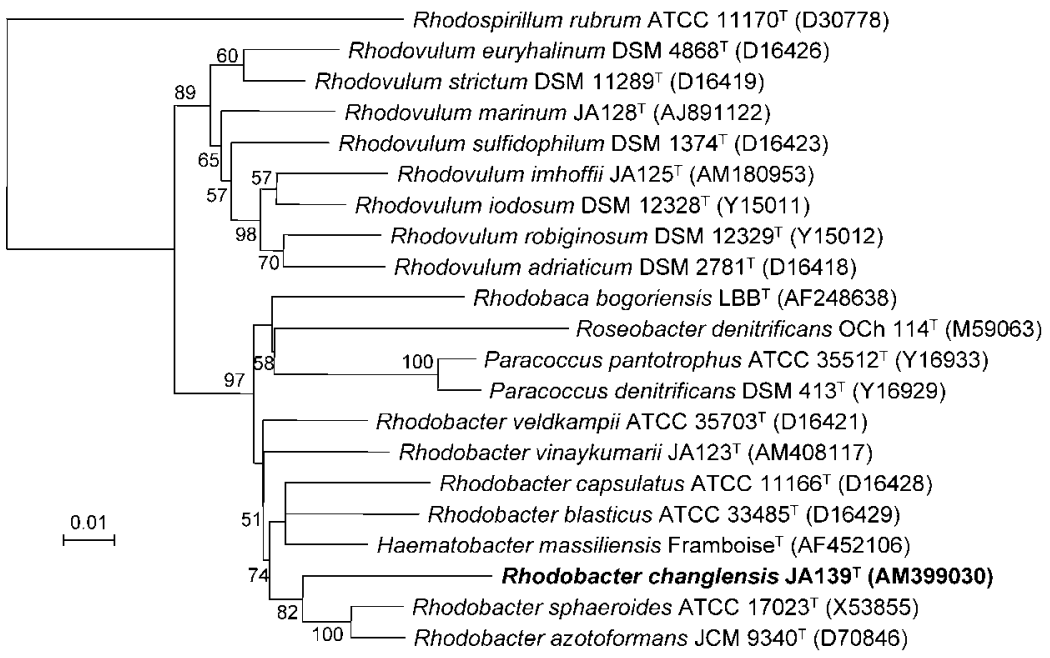

Fig. 1. Dendrogram depicting the phylogenetic relationships of strain $\mathrm{JA} 139^{\top}$ within the family Rhodobacteraceae determined by using 16S rRNA gene sequence analysis. Bar, 1 substitution per 100 nucleotide positions. 
fermentable carbon source. Biotin, niacin and thiamine are required as growth factors. DNA base composition is $69.4 \mathrm{~mol} \% \mathrm{G}+\mathrm{C}$ (by HPLC).

The type strain, $\mathrm{JA} 39^{\mathrm{T}}\left(=\mathrm{DSM} 18774^{\mathrm{T}}=\right.$ CCUG $53722^{\mathrm{T}}$ $=\mathrm{JCM} 14338^{\mathrm{T}}$ ), was isolated from a snow sample collected from Changla Pass in the Indian Himalayas.

\section{Acknowledgements}

Financial assistance was received from the Department of Biotechnology, Government of India. P. A. K. and T. N. R. S. acknowledge the CSIR, Government of India, for the award of SR fellowships.

\section{References}

Felsenstein, J. (1989). PHYLIP (phylogeny inference package), version 3.5.1. Distributed by the author. Department of Genome Sciences, University of Washington, Seattle, USA.
Finneran, K. T., Johnsen, C. V. \& Lovley, D. R. (2003). Rhodoferax ferrireducens sp. nov., a psychrotolerant, facultatively anaerobic bacterium that oxidizes acetate with the reduction of Fe (III). Int $J$ Syst Evol Microbiol 53, 669-673.

Madigan, M. T., Jung, D. O., Woese, C. R. \& Achenbach, L. A. (2000). Rhodoferax antarcticus sp. nov., a moderately psychrophilic purple nonsulfur bacterium isolated from an Antarctic microbial mat. Arch Microbiol 173, 269-277.

Srinivas, T. N. R., Anil Kumar, P., Sasikala, Ch., Ramana, Ch. V., Süling, J. \& Imhoff, J. F. (2006). Rhodovulum marinum sp. nov., a novel phototrophic purple non-sulfur alphaproteobacterium from marine tides of Visakhapatnam, India. Int J Syst Evol Microbiol 56, 1651-1656.

Srinivas, T. N. R., Anil Kumar, P., Sasikala, Ch., Ramana, Ch. V. \& Imhoff, J. F. (2007). Rhodobacter vinaykumarii sp. nov., a marine phototrophic alphaproteobacterium from tidal waters, and emended description of the genus Rhodobacter. Int J Syst Evol Microbiol 57, 1984-1987.

Thompson, J. D., Higgins, D. G., Gibson, T. J., Plewniak, F., Jeanmougin, F. \& Higgins, D. J. (1997). The CLUSTAL_X windows interface: flexible strategies for multiple sequence alignment aided by quality analysis tools. Nucleic Acids Res 25, 4876-4882. 